\title{
Human T-cell leukemia virus type 1 (HTLV-1) Tax oncoprotein induces DNA damages through Activation-Induced cytidine Deaminase (AID)
}

\author{
Aurélien Riquet ${ }^{1,2^{*}}$, Sébastien Chevalier ${ }^{1,2}$, Julien Villaudy ${ }^{3}$, Louis Gazzolo ${ }^{3}$, Jean-Pierre Vartanian ${ }^{4}$, \\ Renaud Mahieux ${ }^{1,2+}$, Madeleine Duc-Dodon ${ }^{3 \dagger}$, Nathalie Bonnefoy ${ }^{5}$ \\ From 16th International Conference on Human Retroviruses: HTLV and Related Viruses \\ Montreal, Canada. 26-30 June 2013
}

How T cells are transformed by HTLV-1 is still unclear, but it is well accepted that the viral oncoprotein Tax is associated with genomic instability of infected cells. Tax has recently been shown to directly induce, in $\mathrm{T}$ cells, the expression of AID (Ishikawa C et al., Carcinogenesis, 2011), a cytidine deaminase whose physiologic expression is usually restricted to B cells, in which it initiates class-switch recombination and somatic hypermutations to reshape the primary antibody repertoire after antigen encounter. It is also well established that AID-mediated mutations outside of immunoglobulin gene locus are involved in the oncogenic transformation of B lymphocytes. Besides its role in B cell lymphomagenesis, AID was recently proposed to play a key role in different human cancers linked to chronic inflammation, or in cancers associated with infectious agents. We first confirmed that both Tax+ and HTLV-1-infected T-cell lines, but not uninfected $\mathrm{T}$ cells expressed aid mRNA as well as AID protein. We further demonstrated that, primary CD4+ T cells and MOLT-4 T-cell line transduced with lentiviral vector expressing Tax expressed high level of AID. More importantly, we also observed a high level of aid in splenic $\mathrm{T}$ lymphoma cells obtained from HTLV-1-infected humanized Rag2 ${ }^{-1}$ gamma $\mathrm{C}^{-1-}$ mice that have developed lymphomas. We demonstrate that AID up-regulation in T cells is associated with DNA damage accumulation. Finally, inhibiting AID expression by small hairpin RNA strategy strongly decreases Taxinduced DNA damages. Altogether our data strongly

\footnotetext{
* Correspondence: aurelien.riquet@inserm.fr

† Contributed equally

'Université de Lyon, Lyon, France

Full list of author information is available at the end of the article
}

suggest that AID is involved in DNA damages and genomic instability of HTLV-1-infected T-cells.

\section{Authors' details}

${ }^{1}$ Université de Lyon, Lyon, France. ${ }^{2}$ Centre International de Recherche en Infectiologie INSERM U1111 - CNRS UMR5308, Université de Lyon, Ecole Normale Supérieure de Lyon, France. ${ }^{3}$ Laboratoire de Biologie Moléculaire de la Cellule, UMR5239 CNRS, Ecole Normale Supérieure de Lyon, Lyon, France. ${ }^{4}$ Unité de Rétrovirologie Moléculaire, Institut Pasteur, Paris, France. ${ }^{5}$ Institut de Recherche en Cancérologie de Montpellier, Inserm U896 - Université Montpellier 1 - CRLC Val d'Aurelle, Montpellier, France.

Published: 7 January 2014

\section{doi:10.1186/1742-4690-11-S1-045}

Cite this article as: Riquet et al:: Human T-cell leukemia virus type 1 (HTLV-1) Tax oncoprotein induces DNA damages through ActivationInduced cytidine Deaminase (AID). Retrovirology 2014 11(Suppl 1):O45.
Submit your next manuscript to BioMed Central and take full advantage of:

- Convenient online submission

- Thorough peer review

- No space constraints or color figure charges

- Immediate publication on acceptance

- Inclusion in PubMed, CAS, Scopus and Google Scholar

- Research which is freely available for redistribution

Submit your manuscript at www.biomedcentral.com/submit
() Biomed Central 